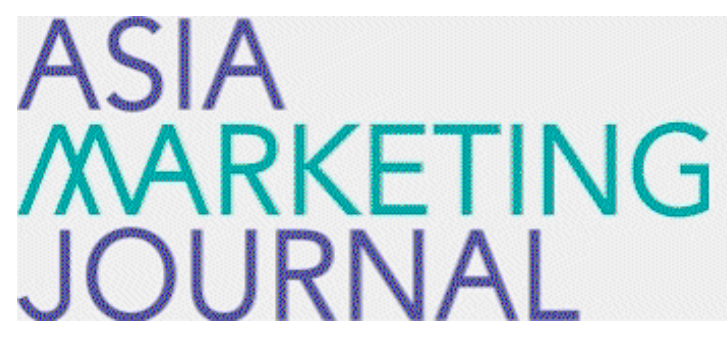

ASIA MARKETING JOURNAL

Volume 7 | Issue 2

Article 2

7-27-2005

\title{
사회자본이론을 통한 사회마케팅의 음용확장에 관한 탐색적 연구
}

Woon Seung Yeo

Follow this and additional works at: https://amj.kma.re.kr/journal

Part of the Marketing Commons

\section{Recommended Citation}

Yeo, Woon Seung (2005) "사회자본이론을 톻한 사회마케팅의 응용확장에 관한 탐색적 연구," Asia Marketing Journal: Vol. 7 : Iss. 2 , Article 2.

Available at: https://doi.org/10.53728/2765-6500.1141

This Article is brought to you for free and open access by Asia Marketing Journal. It has been accepted for inclusion in Asia Marketing Journal by an authorized editor of Asia Marketing Journal. 


\title{
사회자본이론을 통한 사회마케팅의 응용확장에 관한 탐색적 연구* -시장실패와 복잡한 교환의 맥락을 중심으로-
}

\section{Exploring the Application Extension of Social Marketing Based on Social Capital Theory*}

\author{
여 운 승(Yeo, Woon-Seung)**
}

\begin{abstract}
사회마케팅은 1960년대 후반에 마케팅 개념의 확장이 필요하다는 주류 마케팅관리학파에 속하는 일부 학자들의 주장이 제기되면서 태동되었다. 이러한 이유로 인하여 사회마케팅 종사자들은 주로 전 통적인 마케팅 수단에 의존하여 사회적 문제를 다루는데 응용하여왔다. 그러나 사회마케팅에 관한 지 금까지의 연구문헌을 보면 사회마케팅 종사자들이 상업마케팅의 경우와는 매우 상이한 상황이라 할 수 있는 시장실패와 복잡한 교환을 간과하고 있음을 알 수 있다. 따라서 사회마케팅은 이러한 상황에 직면하고 있음을 고려할 때 전통적인 수단만으로는 사회적 문제를 충분히 다룰 수 없다. 이에 따라 본 연구에서는 사회자본이론이 시장실패와 복잡한 교환현상은 물론 행동변화와 사회적 현상도 고려 하고 있기 때문에 사회마케팅 종사자들에게 유용한다는 점을 보여주었다. 사회자본이론을 사회마케팀 에 원용하면 사회마케팅 종사자들이 유익한 행동변화를 추구하는데 하나의 지침이 될 것이다.
\end{abstract}

핵심개념: 외부성, 복잡한 교환, 마케팅컨셉, 시장실패, 사회적 자본이론, 사회마케팅

\section{I. 머리말}

지난 40 년간 사회마케팅은 상업마케팅의 개념 을 원용하여 다수의 사회적 문제를 다루는데 천착하여 왔고, 21 세기에 들어서면서도 이에 관
한 인식이 높아지고 사회적 변화에 대해 혁신 적 접근방법을 수용하는데 성과를 거두고 있다. 그러나 아직까지도 사회마케팅의 범위에 관하 여 연구자들간에 견해가 일치하지 않고 연구의 초점에도 많은 변동이 있었다.' Andreasen(2002) 은 사회마케팅의 현재 상황을 종합적으로 평가

* 이 논문은 2004년 한양대학교 일반연구비 지원으로 연구되었음.

** 한양대확교 경영학부 교수(yeows@hanyang.ac.kr)

1) 예컨대 사회마케팅 (social marketing)은 마케팅 개념을 확장하여 주로 비영리기관에서 적용할 수 있는 것으로 인정되어 왔으며 사회지향적 마케팅(societal marketing)은 영리를 추구하는 기업이 단순히 마케팅 개념(marketing concept)에 집 착하여 고객의 욕구를 충족하는 것만으로는 그 사명을 완수할 수 없고 마케팅 활동으로 사회에 미치는 악영향(예컨대 
하면서 이 분야가 앞으로 성장하는데 대두될 장애요인들을 열거한 바 있다. 그러므로 이를 극복할 방법이 무엇인가를 이해하는 것이 해결 책을 제공할 단서가 될 것이다.

이에 따라 본 연구에서는 사회마케팅의 기원 과 발전과정을 살펴보고, 그동안의 연구성과물 을 토대로 사회마케팅 종사자들이 추구하여 온 목적 내지 수단에 어떠한 차이가 있는가를 발 견하는 것을 연구의 출발점으로 삼고자 한다. 일반적으로 사회마케팅 분야에 종사하는 사랍 들간에 사회적 변화를 적극적으로 창출하기 위 하여 마케팅 개념을 이용하여 유사한 목표를 달성한다는 데에는 일치된 입장을 보이고 있으 나 그러한 목표를 달성하기 위한 수단에 차이 가 있음을 발견할 수 있다. 앞으로 본론에서 상 술하겠지만, 사회마케팅에 관한 지금까지의 연 구문헌은 사회마케팅 종사자들이 옹호하는 수 단을 토대로 두 가지로 분류할 수 있다. 그 하 나는 전통주의적 접근방법을 택하는 것으로 마 케팅 믹스 구성요소의 일부 또는 전부를 이용 하는데 초점을 두는 주류 마케팅관리학파의 마 케팅 원리에 의존하는 방식이다. 다른 하나는 사회마케팅 연구에 학제간 접근방법을 택하는 것이다. 전통주의적 접근방법에서는 사회마케팅 에 관하여 대체로 신고전적 방식을 취하여 자 연히 전통적인 상업마케팅 원리를 채택하는 경 향이 있다. 그러나 사회마케팅 분야를 발전시키 려면 전통적인 마케팅 영역내에서 뿐만 아니라 이를 벗어나 사회적 문제를 다룰 학제간 접근 방법도 필오한 것으로 나타나고 있다. 그 이유
중의 하나는 사회마케팅 종사자들이 상업마 케팅에 비하여 다소 상이한 상황 하에서 활 동하고 있기 때문이다. 대표적인 예로 시장실패 (market failure)를 들 수 있다. 시장실패는 모 든 마케팅 종사자들이 당면하고 있는 문제이긴 하지만 특히 사회마케팅에서 다룰 될요가 있음 에도 불구하고 사회마케팅 종사자들이 지금까 지 다루고 있지 않아 심층적으로 연구될 필요 가 있다. 또 하나의 예로 교환의 개념을 들 수 있다. 상업마케팅에서는 주로 두 당사자간에 경 제적 가치가 있는 것을 거래하는 제한된 의미 의 교환을 다루고 있는 반면에, 사회마케팅에서 는 셋 이상의 당사자간에 거래가 이루어지는 보 다 복잡한 교환을 다루고 있다(Bagozzi 1975). 이러한 시장실패와 복잡한 교환의 개념에 대해 서는 본론에서 상술하기로 한다.

본 연구에서는 사회자본이론(social capital theory)에 초점을 두어, 이것이 시장실패와 복 잡한 교환의 개념뿐만 아니라 행동이나 사회적 문제들도 고려하고 있다는 점에서 사회마케팅 을 보강할 수 있는 장점이 있음을 보이고자 한 다. 이와 더불어 본 연구는 학제간 접근방법이 사회마케팅에 적절하다는 입장을 취하고 있다. 그러나 학제간 접근방법은 사회적 현상을 따로 분리하여 검토하는 경향이 있으나 사회자본이 론은 전통주의적 접근방법도 포괄하고 있다는 장점이 있다. 따라서 본 연구는 전통주의적 접 근방법을 간과하고 있지 않다는 점에서 단순한 학제간 접근방법과 차이가 있다. 이에 따라 본 연구에서는 사회자본이론이 사회마케팅 연구자

왜곡된 소비욕구의 조장이나 환경오염 등)도 고려하여 소비자와 대중을 비롯한 모든 관계당사자들과의 이해관계도 조정 하여야 한다는 점을 강조하고 있다. 따라서 양자의 개념은 근본적으로 차이가 있기 때문에 사회지향적 마케팅은 사회마 케팅의 범주에 속하지 않는 것으로 본다. 
들이나 실무자들이 이용할 수 있는 기존의 수 단을 보강하고 지침이 될 가교역할을 할 것임 을 보이고자 한다.

\section{II. 사회마케팅의 발전과정과 문헌의 유형}

\section{1 사회마케팅의 기원과 발전과정}

사회마케팅에 관한 최초의 착상은 형제애(brotherhood)(또는 박애정신)를 비누와 같은 상품 으로 판매할 수 있을 것으로 제안한 바 있는 사회학자 Wiebe(1951-52)의 논문에서 찾아볼 수 있다. 이때부터 사람들은 상업부문에서 인간 의 행동에 영향을 미치는데 성공적으로 이용되 었던 방법들을 비영리 부문에도 응용할 것을 신중하게 고려하기 시작하였다. Wiebe(1952-52) 는 네 가지의 상이한 사회적 변화 캠페인을 평 가하여 이들이 상업마케팅과 유사할수록 성공 할 확률도 높을 것으로 결론을 맺은바 있다.

그 이후 마케팅 학계에서 관심을 기울이기 시 작하여 1969년에 Kotler and Levy(1969)는 마 케팅 종사자들이 마케팅 분야에 대하여 지나치 게 좁은 시각을 지니고 있다고 비판하면서, '마 케팅은 치약이나 비누. 철강과 같은 상품만을 판매하는 범위를 벗어나 포괄적인 사회지향적 활동'이라고 주장함으로써 마케팅 개념의 확장 을 촉구하였다. 흔히 인용되고 있는 이 논문은 마케팅 개념의 확장을 제안한 것 외에도 그 이 후 사회마케팅을 학계나 실무계에 도입하는데 결정적 역할을 한 것으로 볼 수 있다. 뿐만 아
니라 이 논문은 사회마케팅을 도입하는데 두 가지 면에서 크게 기여하였다. 즉, 제품과 한 기관이 대상으로 삼고 있는 고객에 대한 개념 을 재정립할 필요가 있음을 제안한 것이다. 예 컨대 '제품'이란 용어는 유형의 상품뿐만 아니 라 서비스, 인물, 기관 및 아이디어 등도 포함 된다고 제안하였다. 지금까지 사회마케팅은 '아 이디어'를 촉진하는 것으로 흔히 간주되고 있 다. 또 하나는 기업을 포함하여 한 기관이 대상 으로 삼고 있는 고객에는 단순히 소비자뿐만 아니라 종업원, 원료 및 부품공급자, 유통종사 자, 주주, 조직의 임원 및 일반 대중도 포함된 다고 주장한 것이다. 이러한 고객들 가운데 '일 반 대중'은 사회마케팅 종사자들의 표적집단 이다.

마케팅의 개념을 확장할 필요가 있다는 Kotler and Levy(1969)의 이러한 주장에 대해 학계에 서는 폭넓은 지지를 받았으나, 모든 연구자들이 긍정적인 반응을 보이지는 않았다. 일부 논자들 은 Kotler and Levy의 논문이 개념상 과장되었 을 뿐만 아니라 확장된 개념의 복잡성도 고려 하지 않았고(Enis 1973) 개념 확장을 통하여 얻을 수 있는 이점과 결과도 언급하고 있지 않 았으며(Bartels 1974: Enis 1973: Tucker 1974). 실제로 마케팅의 개념을 명백하게 재규정하지 도 못하였다(Enis 1973: Luck 1969,1974)고 비 판하였다. 또 다른 비판은 확장된 개념이 교환 과정에 미치는 영향에 대해 주의를 기울이지 못하였다는 것이다. 일부 논자들은 확장된 마케 팅 개념하에서 실제 교환과정의 형태와 명료성 은 물론 그 존재에 대해서도 의문을 제기하였 다(Enis 1973: Foxall 1989). 그들의 주장에 의 하면 개념상 마케팅의 범위를 확장한다면 전통 
적인 교환과정은 부적절한 준거틀일 수 있다.

이와 같이 Kotler and Levy(1969)의 논문에 대해서 비판도 있었지만, 이 논문은 마케팅 분야 에서 미래의 인식론적 발전의 계기를 만들었다 고 할 수 있다. 그 후 Kotler and Zaltman(1971) 은 그 연장선상에서 사회적 변화를 진척시키는 데 전통적인 마케팅 원리와 전략을 응용하는 것 이 유용하다고 주장함으로써 최초로 '사회마케 팅'(social marketing)이라는 용어를 소개하였다. 그들이 이러한 용어를 사용한 것은 마케팅이란 하나의 기술이고 이러한 기술은 사회적 문제에 응용할 수 있다고 보았기 때문이다. 또한 Kotler(1972)는 마케팅의 개념을 연장하여 조직 과 대중간의 모든 거래를 포함한다고 보았다.

학계에서 사회마케팅의 개념을 정의하기 시작 한 초기에는 이에 관하여 논란이 있었으나 당 시에 정의된 개념에는 그 후 오늘날까지 두 가 지 면에서 혼란이 있었다. 첫째, Kotler and Zaltman(1971)은 사회마케팅을 '사회적 아이디 어를 대중들이 수용하도록 영향을 미치기 위하 여 제품계희, 가격결정, 촉진, 유통 및 마케팅 조사등을 포함한 프로그램을 설계하고 시행하 며 통제하는 것'이라고 정의하였으나, 이러한 정의에는 사회마케팅이 '비영리 마케팅'을 지칭 하고 있는지의 여부와 상업마케팅이 '사회적 책 임이 있는 마케팅'도 포함하고 있는가를 명백하 게 가리키고 있지 못하고 있다. 둘째, Kotler and Zaltman(1971)이 제안한 정의에는 사회마케팅 이 단순한 '사회광고' 또는 공익광고나 $\mathrm{PR}$, 혹 은 극단적으로 말하면 단순한 교육과 혼동하고 있는 것처럼 보인다.

이와 같이 1970년대에 학계에서 마케팅 개념 의 확장에 대해 의문을 제기하였으나, 이와 동
시에 사회마케팅과 상업마케팅이 전통적인 마 케팅 원리를 원용하고 있는 공통점이 있어 사 회마케팅의 의의를 수용하고 그 타당성을 인정 하기 시작하였다. 그 후 1980년대에는 사회마케 팅에 관한 논쟁이 종식되고 연구자들은 사회마 케팅을 어떻게 실행하여야 할 것인가에 관하여 탐구하기 시작하였다. 1980년대에 이루어진 사 회마케팅에 관한 연구는 대부분 신고전적 접근 방법을 이용하였으며 사회마케팅 환경내에서 상업마케팅 원리를 적용하는데 주로 초점을 두 는 경향이 있었다(Ornstein and Hanssens 1985).

다른 한편, 사회마케팅의 개념이 명백하게 규 정되지는 않았지만 1960 년대를 통하여 의료보 건과 개발경제 분야에서 이를 실행하고 있었다 (Walsh et al. 1993). 그 이후 사회마케팅은 환 경문제 등을 비롯하여 여러 분야에서 연구가 진행되었으나 대부분이 약물남용 등 의료보건 분야에 관한 것이었다. 일부 연구자들은 사회마 케팅에서의 윤리의 역할에 관하여 탐구하였고 (Brenkert 2002; Laczniak et al. 1979; Tansey et al. 1992) 또 일부는 사회마케팅의 성장 가능 성을 검토하기도 하였다(Andreasen 1994, 2002).

Andreasen(2002)에 의하면 사회마케팅 연구 자들은 지난 20 년간 고유의 정체성을 찾으려는 노력을 기울여왔다. 이것은 사회마케팅이 하나 의 독자적 분야 내지 학제로까지 발전하지 못 하였다는 비판(Sheth and Parvatiyar 2002)을 반영한다고 볼 수도 있다. 그러나 Andreasen (1994)에 의하면 '사회마케팅이란 표적청중의 개인적 복지와 그들이 속해 있는 사회의 복지 를 개선하기 위하여 그들의 자발적 행동에 영 향을 미칠 것을 목적으로 하는 프로그램을 분 석, 계획, 실행 및 평가하는데 상업마케팅의 기 
술을 응용하는 것'이다. 따라서 이러한 정의에 의하면 오늘날 사회마케팅의 핵심적 역할은 사 회가 누릴 수 있는 보다 넓은 범위의 효익을 위하여 사회적 변화에 영향을 미치기 위한 수 단으로 아이디어를 촉진시키기 보다는 행동에 영향을 미치려는데 있다고 본다.

\section{2 사회마케팅의 목적달성을 위한 수단에 의한 문헌의 유형}

지금까지 연구된 사회마케팅에 관한 문헌들을 보면 마케팅 종사자들이 달성하고자 하는 목적 은 적극적인 사회적 변화를 추구하는 하나의 공 통점을 지니고 있으나, 그러한 목적을 달성하기 위한 수단 내지 도구에는 차이가 있음을 알 수 있다. 이러한 면에서 본 연구에서는 사회마케팅 종사자들이 사회적 변화를 달성하기 위하여 이 용하고 있는 수단을 토대로 사회마케팅에 관한 문헌을 두 가지로 대별하고자 한다. 그 하나는 전통주의적 접근방법으로 통상적인 상업마케팅 의 원리를 직접 원용하는 것이다. 다른 하나는 학제간 접근방법으로서 사회마케팅을 연구하는 데 학제간 접목을 시도함과 아울러 상업마케팅 의 범위를 벗어난 여타 수단들을 이용하는 것이다.

\section{2 .1 전통주의적 접근방법}

전통적인 마케팅 수단을 사회마케팅 영역에 이용하는 것은 합리적 경제행위 모델에 의존하 고 있음을 뜻한다(Mckenzie-Mohr 1994: Sirgy et al. 1985). 전통주의적 접근방법은 의도적이 든 또는 그렇지 않든 간에 상업마케팅에서 택 하고 있는 것과 동일한 마케팅 수단을 사회마
케팅 영역에 이용하고 있다. 이러한 접근방법은 신고전 이론에 근거하고 있다는 공통점을 지니 고 있으나 어떤 수단에 초점을 두고 있는가에 따라 약간의 차이가 있으며, 이에 따라 다시 두 가지 유형으로 분류할 수 있다. 그 하나는 마케 팅 믹스 중심의 접근방법으로서 일반적으로 마 케팅 믹스 구성요소의 일부에만 초점을 두고 있으며. 또 하나는 전략적 접근방법으로서 대체 로 다수의 마케팅 믹스 요소와 보다 전략적 관 점을 채택하고 있다.

\section{(1) 마케팅 믹스 중심의 접근방법}

이 접근방법에서는 마케팅 믹스의 구성요소 중 하나 또는 두 개 정도의 요소에 중점을 두 고 있다. 이와 더불어 지금까지도 Kotler and Zaltman(1971)이 제안한 착상을 따라 사회마케 팅이 아이디어를 촉진하는 것이라는 소박한 입 장을 견지하고 있는 경향이 있다. 이러한 입장 은 Fox와 Kotler(1980)가 사회마케팅 영역에는 마케팅 믹스 요소 중에 촉진만이 쉽사리 이용 될 수 있다고 주장함으로써 더욱 강화되었다. 1980년대에 연구된 마케팅 믹스 중심적 문헌은 대부분 사회마케팅에서 촉진의 역할에 집중된 접근방법이 주류를 이루고 있다(Barach 1984). 그러나 소수의 예외적인 문헌을 찾아볼 수 있 다. 예컨대 Andreasen(1984)의 연구는 비록 이 론적인데 그치고 있지만 유통에 초점을 두었고. Ornstein and Hanssens(1985)는 가격이 알콜 소비에 미치는 영향을 조사한 바 있다. 1990년 대에도 촉진에 역점을 둔 연구가 대부분이었으 며 21세기에 들어서도 지속되고 있다(Jones 2001; Peattie et al. 2001; Reichert et al. 2001; 김지민, 이상빈, 리대용 2002: 신준섭, 최은미 
2004).

지금까지 사회마케팅에 관한 마케팅 믹스 중 심의 연구문헌 가운데 유통이나 제품 또는 가 격에 초점을 둔 경우는 매우 드물다. 이것은 사 회마케팅의 복잡성에 비추어 볼 때 마케팅 믹 스의 요소 중 하나만을 놓고 연구의 초점을 두 는 것은 적절하지 않으며 복수의 요소를 동시 에 고려하는 것이 바람직하다는 것을 시사하고 있다. 오직 촉진만이 유익한 사회적 변화를 일 으키는 유일한 처방책이라는 논거는 직관적으 로 보더라도 수용하기 어렵다. 마케팅 믹스 중 심의 접근방법은 극히 일부의 요소만을 고려함 으로써 보다 포괄적인 마케팅 철학을 반영하지 못하고 있다. 이러한 점에서 본 연구에서는 사 회자본이론이 사회마케팅에 관한 연구를 보강 할 수 있는 긴요한 도구임을 보이고자 한다.

\section{(2) 전략적 접근방법}

전략적 접근방법은 마케팅 중심의 접근방법에 비하여 두 가지 면에서 차이가 있다. 첫째, 전 랴적 접근방법에서는 마케팅 믹스의 모든 요소 가 필수적이라고 보며, 둘째, 사회마케팀에서 전략이 중요한 역할을 수행한다고 간주한다. 이 방법은 세 가지로 분류된다. 즉, 마케팅 믹스의 모든 요소를 이용할 것을 옹호하는 입장, 전략 을 수립, 실행하고 통제하지만 마케팅 믹스의 역할을 간과하는 입장, 그리고 마케팅 믹스와 마케팅 전량을 모두 고려하는 총체적 접근방법 을 택하는 경우로 나눌 수 있다.

사회마케팅에서 마케팅 믹스의 모든 요소를 이용하는 연구에 대해서는 관심은 있었으나 활 성화되지 못한 것으로 생각된다. 그 이유는 문 헌상 사회마케팅 문제들에 대하여 마케팅 믹스
를 이용할 명백한 방향이나 처방이 나와 있지 않고 마케팅 믹스를 포괄적으로 이용하는데 따 르는 난점이 있었기 때문이다(Bloom and Novelli 1981: Fox and Kotler 1980). Bloom and Novelli (1981)는 사회적 재화(social goods)를 판매하는 데 따르는 장애요인을 인식하여 사회적 재화는 소비자 욕구를 충족시키기 위하여 변경하기가 어렵고, 가격도 소비자들의 주관적 판단에 따라 좌우되어 결정하기 어려우며, 유통과 촉진활동 에 필요한 자금조달이 어려운 점 등을 열거한 바 있다. 총체적 마케팅 믹스를 포함하여 전통 적인 마케팅 수단이 사회마케팅 종사자들이 당 면하고 있는 시장실패의 성격을 다루는데 다소 적절하지 못하다는 것이 분명하다. 제품, 가격, 유통 및 촉진의 성격에 대한 관점은 증폭된 시 장실패를 규정하는 환경내에서 보다 적절하게 적용할 수 있도록 바뀌어야 할 필요가 있다.

다른 한편 사회마케팅에서 전략의 역할(즉 사 회마케팅 전략의 수립과 시행 및 통제의 역할) 에만 초점을 둔 연구문헌도 찾아볼 수 있다 (Black and Farley 1979; Brown et al. 2000; David and Greer 2001; Price 2001; 김수영 2001). 이러한 연구들은 전략수립과정에 초점을 두는 정도에 약간 차이가 있다. 대부분은 사회 마케팅 전략의 수립에 역점을 두고 있고 실행 의 역할을 간과하는 경향이 있다. 그 이유는 사 회마케팅 종사자들이 불확실한 환경하에서 전 략을 시행하는데 따르는 어려움을 인식하고 있 기 때문이다(Steiner 1979). 그러나 사회마케팅 종사자들은 사회마케팅 환경내에서 불확실성이 시장실패와 같은 요인으로 중첩된다는 점을 인 식하지 못하고 있다. Bloom and Novelli(1981) 도 사회마케팅 전략을 수립하는데 따르는 난점 
을 지적하면서 시장조사를 위한 자금의 제약으로 시장세분화와 표적집단 선정 및 포지쇼닝 노력이 부족하다고 주장하였다. 그들은 특정 기관이 제공 하는 것을 수용하려는 표적시장의 동기가 부족하 고 전략의 효과를 점검하기가 어려운 이유로 인 하여 그와 같은 문제가 더욱 가중된다고 보았다.

마지막으로 마케팅 믹스와 마케팅 전략을 모 두 포괄하는 총체적 접근방법을 택하고 있는 연구문헌들도 있다(Cirksena and Flora 1995; Golden and Johnson 1991: Smith 2000; 부경 희 2001). 그러나 이러한 문헌들도 마케팅 중심 적 접근방법이나 전략중심 접근방법과 마찬가 지로 사회마케팅이 당면하고 있는 시장실패의 성격을 제대로 다루지 못하고 있다.

\section{2 .2 학제간 접근방법}

학제간 접근방법은 전통주의적 접근방법에 비 하여 사회적 문제를 다루는데 마케팅 영역외의 학제 내지 분야에 의존하고 있다는 점에서 기 본적인 차이가 있다. 이러한 학제간 접근방법은 대체로 개인적 접근방법과 사회적 접근방법으 로 나눌 수 있다. 전자의 경우에는 삶의 질 이 론(Sirgy et al. 1985) 과 확산이론(Martin et al. 1998) 등을 이용하며, 후자의 경우에는 집단적 희생(Wiener 1993), 사회화(Moor et al. 2002) 등과 같은 요인을 다루는 이론과 사회심리학 (Mckenzie-Mohr 1994) 등의 이론을 원용하여 사회마케팅을 연구하는데 사회적 내지 관계적 접근방법을 택하고 있다.

이러한 학제간 접근방법은 전통주의적 접근방 법에 비하여 연구문헌이 훨씬 적지만 보다 광 범위한 문제들을 다루고 있다. 예컨대 의료보
건, 약물남용, 환경문제 및 시민참여운동을 들 수 있다. 지금까지 학제간 접근방법에 의한 두 가지 유형의 문헌 가운데 사회적 접근방법이 개인적 접근방법보다 더 적절하다고 볼 수 있 다. 그 이유는 사회마케팅 분야가 기본적으로 '사회적' 성격을 지니고 있기 때문이다. 개인적 접근방법을 택하고 있는 이론들은 사회마케팅 이 '사회적' 내지 복합적 성격을 포착하지 못하 고 있기 때문에 사회마케팅에서 당면하고 있는 문제의 해결에는 적절하지 못한 것으로 생각된 다. 이것은 앞에서 알 수 있었던 바와 같이 전 통주의적 접근방법에서도 제기되는 문제이다. 그럼에도 불구하고 사회마케팅 환경하에서 사 회적 관계나 교환이 복잡한 것이라면 학제간 접근방법을 선호하는 연구자들이 동태적이고 상호작용하는 다수의 사회적 현상을 따로 분리 하여 바라본다는 것은 문제가 아닐 수 없다.

\section{III. 상업마케팅과 사회마케팅간의 상황적 차이}

사회마케팅이 작동되는 배후의 상황을 이해하 려면 교환과 시장에 관한 착상을 탐구할 필요 가 있다. 그 이유는 교환과 시장 내에 존재하고 있는 차이가 곧 사회마케팅과 전통적인 상업마 케팅을 구분할 수요 요소이기 때문이다.

\section{1 전통적 마케팅과 사회마케팅에서의 교환의 개념}

사회마케팅의 체계에 대해서는 다수의 상이한 
견해가 제시되어 왔으나 넓은 의미에서 본다면 세 가지 구성요소가 핵심이라는데 대체로 공감 하고 있다. 세 가지 핵심 요소란 장기적 초점, 고객 지향성 및 교환을 말한다. 장기적 초점은 원래 Kotler and Zaltman(1971)이 제시한 것으 로 사회마케팅이 전략적임을 뜻하고 있다. 사회 마케팅이 장기적으로 초점을 둘 필요가 있는 이유는 사회적 변화를 시도하는 거대한 과업을 다루고 있기 때문이다. 주류 마케팅과 마찬가지 로 사회마케팅에서도 소비자의 욕구에 귀를 기 울이고 대응하는 것이 필수적이다(Andreasen 1994). 그러나 소비자에 관한 여러 개념 가운데 한 가지 면에서 차이가 있다. 즉, 전통적 마케 팅에서는 소비자 개인이나 하나의 조직에 중점 을 두고 있으나 사회마케팅에서는 일반 대중이 나 보다 넓은 사회에 주로 초점을 두고 있다. 사회마케팅 종사자들은 소비자 개인의 욕구를 충족시키기보다는 사회복지를 극대화하는데 관 심을 기울일 경우가 많다.

교환은 전통적 마케팅과 마찬가지로 사회마캐 팅 배후의 핵심적 철학이다(Bagozzi 1975; Kotler and Zaltman 1971). 좁은 의미의 교환은 순전 히 경제적 논리를 따라 두 당사자간에 거래가 이루어지는 과정을 뜻한다. 이와 같이 좁은 의 미의 교환개념을 지지하는 측에서는 교환의 개 념을 확장하면 마케팅의 정체성이 상실될 수 있다고 주장한다(Laczniak and Michie 1979). 그럼에도 불구하고 Bagozzi(1975)를 비롯한 여 러 연구자들이 이러한 좁은 시각의 교환개념을 확장하려는 노력을 기울였고, 확장된 교환개념 이 점차 수용되었다. 마케팅 개념을 확장할 필 요가 있는가의 여부와 어떠한 방법으로 확장되 어야 하는가에 관한 논의는 마케팅 종사자들이
교환과정을 어떻게 보고 있는가와 밀접한 관련 이 있다.

교환의 개념을 확장하는데 Bagozzi(1975)가 주로 기여한 것은 마케팅 교환의 영역안에 사 회적 관계를 포함시켰다는데 있다. 그는 마케팅 영역에 포함되는 교환의 유형을 한정된 교환. 보편적 교환 및 복합적 교환 등 세 가지로 분 류하고 그 성격을 개괄적으로 언급한 바 있다. 한정된 교환이란 위에서 언급한 좁은 의미의 교환을 뜻하며, 보편적 교환이란 셋 또는 그 이 상의 행위자들간의 단선적 상호관계 시스템으 로 구성되어 있는 것을 가리키고, 복합적 교환 도 최소한 3 인 또는 그 이상의 행위자들간의 상호관계가 내포되지만 보편적 교환과는 달리 호혜적이고 장기적 기간이 필요하다. Bagozzi (1975)는 사회마케팅에서의 교환은 보편적 교 환이나 복합적 교환으로 보고 있으며. 본고에서 는 양자를 합하여 '복잡한 교환'이라는 용어를 사용하기로 한다. 일반적으로 전통적 마케팅에 서는 한정된 교환의 개넘에 치중하는 경향이 있고 사회마케팅에서는 보편적 교환과 복합적 교환에 초점을 두고 있다. 이와 아울러 마케팅 은 물론 사회마케팅에서도 교환으로 인하여 공 식적으로나 비공식적으로 영향을 받게 되는 모 든 당사자들을 고려하여야 한다는 점을 강조할 필요가 있다.

Bagozzi(1975)에 의하면 교환의 내용은 실용 적인 것(경제적이고 상대적으로 유형적인 것), 상징적인 것(심리적. 사회적이고 무형적인 것), 그리고 양자가 혼합된 것으로 나눌 수 있다. 그 에 의하면 대부분의 교환은 혼합된 것에 속한 다. 과거에 사회마케팅 하에서의 교환의 내용은 사회마케팅 종사자들이 콘돔이나 피임약과 같 
이 비교적 유형의 제품에 마케팅 활동의 초점 을 두면서도 혼합적인 경항을 보이고 있었다 (Andreasen 2002). 그 후 시간이 경과함에 따 라 교환의 개념이 보다 광범위한 사회적 목적 달성을 위하여 응용되기 시작하면서 교환의 내 용은 점차 보다 상징적인 성격을 지니게 되었 다(Andreasen 2002).

\section{2 사회마케팅 환경에서의 시장과 시장 실패}

마케팅의 필요성은 교환에 참여하는 구매자와 판매자의 존재에서 비롯된다는 것이 일반적인 통념이다. 다시 말하면 시장이 있는 곳에 마케 팅의 필요가 있다(Kotler 1988, p.9). 마케팅은 본질적으로 소비자의 욕망에 의하여 성립된다. 그리고 자원의 희소성으로 인하여 시장이 존재 하며, 자원의 희소성이 인간의 욕구와 욕망에 대한 동기를 유발시킨다(Maslow 1954). 그러나 마케팅에서는 시장이 효율적으로 작동되고 있 는가의 여부와 시장이 실패하고 있는가의 여부 에 대해서 그다지 관심을 기울이지 않을 경우 가 많다.

시장실패(market failure)는 시장과정 내지 교 환이 희소한 자원을 비효율적으로 배분하는 결 과를 가져올 때 발생하며, 사회의 복지를 극대 화하기보다 감소시킨다(이준구 2004). 이러한 시장실패가 초래되는 요인에 대해서는 학자들 간에 여러 가지를 제시하고 있으나 일반적으로 중시되는 요인으로 공공재(public goods)와 외 부성(externalities)을 꼽을 수 있다(이준구 2004). 공공재는 두 가지 특성을 갖고 있다. 그 하나는 비경합성(non-rivalry)이다. 비경합성이란 예컨
대 우리가 보통 접하는 상품들은 한 사람이 소 비한 만큼 다른 사람의 소비가능성이 줄어든다 는 의미에서 경합성을 갖고 있으나, 국방서비스 와 같은 공공재의 경우에는 어떤 사람이 그 혜 택을 받았다 해서 다른 사람이 받을 수 있는 혜택이 줄어들지 않는 것을 말한다. 따라서 아 무리 많은 수의 사람이라 하더라도 모두, 그리 고 동시에 국방서비스의 혜택을 누릴 수 있다 는 의미에서 비경합성을 갖는다고 말한다. 공공 재가 갖는 두 번째 특성은 배제불가능성(nonexcludability)이다. 다시 말하면 공공재에 대해 대가를 지불하지 않은 사람이라 해도 그것을 소비하지 못하게 할 수 없다는 특성이 있다. 예 컨대 국방서비스의 경우, 그 금액을 지불하지 않는 사람만 골라 그 서비스를 받지 못하게 할 수 없는 것과 같다. 공공재의 이러한 두 가지 특성으로 인하여 사람들은 무임승차의 유혹을 갖게 된다.

위에서 언급한 바와 같이 또 다른 시장실패의 요인으로 외부성을 들 수 있으며, 본 연구에서 는 이에 초점을 두고자 한다. 본 연구에서 외부 성에 초점을 두는 이유는 외부성으로 인하여 초래된 시장실패의 환경내에서 사회마케팅이 존재한다고 생각되기 때문이다. Foxall(1989. p.10)이 사회마케팅은 …......시장을 과다하게 만든다: 그것은 소비자의 선택이나 시장 메카 니즘의 작동이 들어설 여지를 갖고 있지 않다 라고 주장한 것은 곧 시장실패의 존재를 시사 하고 있다. 본 연구에서는 마케팅은 물론 특히 사회마케팅이 점증되고있는 시장실패의 상황에 필요하고도 보다 도전할 만한 분야임을 내세우 고자 한다. 도전할 만한 가치가 있는 이유는 명 백하다. 어느 한 사람이 교환에 참여하려는 인 
센티브를 갖고 있지 않은 사람에게 어떠한 방 법으로 판매할 것인가? 어느 한 사람이 교환관 계에서 다른 사람에게 '적절하게' 행동하도록 시도하면서도 교환에 참여하지 않는 사람들에 게 영향을 미치지 않도록 하려면 어떻게 해야 할 것인가? 본고에서는 이러한 문제들에 대하 여 보다 상세하게 탐구하기로 한다.

공식적으로는 교환의 당사자가 아닌 사람들이 그러한 교환의 과정이나 결과에 따라 영향을 받을 때 외부성이 존재하게 된다. 영향을 받게 되는 측에서 교환의 당사자가 될 의도가 없는 데도 교환을 다루지 않을 수 없게 되는 것이다. 달리 말하면, 어떤 한 사람의 행동이 제 3 자에게 의도하지 않은 이득이나 손해를 끼치는데도 이 에 대한 대가를 받지도 지불하지도 않을 때 외 부성이 발생하며. 이처럼 대가를 주고받지 않기 때문에 시장의 테두리 밖에서 존재하는 현상으 로 볼 수 있다는 의미에서 외부성이라는 명칭 이 부여된다. 이러한 외부성은 교환이 자발적이 라는 착상(Kotler and Zaltman 1971) 과는 모순 되는 경향이 있다. 전통적인 마케팅과 마찬가지 로 사회마케팅에서도 교환은 자발적이며 마케 팅 종사자들은 개인이나 집단이 특별히 필요로 하거나 원하는 것을 제공할 필요가 있다고 가 정하고 있다. 그러나 앞에서 알 수 있었던 바와 같이 개인의 욕구나 욕망이 흔히 더 커다란 이 득을 위해 희생되는 것처럼(Sirgy et al. 1985) 교환이 반드시 자발적인 것은 아니다. 교환의 결과는 이로울 수도 있고(긍정적 외부성) 해로 울 수도 있다(부정적 외부성). 또한 외부성은 경제학에서 '일출효과'(spillover effects)라고도 하며, 그 명칭이 시사하고 있는 바와 같이 최적 량의 재화가 반드시 생산되거나 소비되지는 않
으며 그러한 재화의 교환으로 제 3 자가 영향을 받을 수 있다.

긍정적 외부성의 예로 면역성이 부여되는 경 우를 들 수 있다. 면역성이 부여되면 사회적으 로 커다란 비용이 초래될 수 있는 질병의 확산 을 막을 수 있으며 전체 사회가 면역을 위한 예방접종에 참여하여야 한다. 그럼에도 불구하 고 면역을 위한 예방접종을 받지 않은 사람도 받은 사랍으로부터 이득을 보게 되는 것이다. 이러한 긍정적 외부성이 존재할 경우에는 최선 이 아닌 차선의 최적 교환량이 산출되는 경향 이 있다. 그러나 문제는 여전히 남아 있다. 즉, 이러한 교환에 참여하지 않은 제 3 자들에게도 어떠한 방법으로 면역성을 부여하여 그들의 책 임을 다하도록 할 것인가?

부정적 외부성의 예로는 수동적 흡연의 경우 를 들 수 있다. 담배를 피우지 않는 사람들(즉 교환의 당사자가 아닌 사람들)은 같은 방에서 담배를 피우는 사람들과 함께 있으면 매연 속 에서 숨을 쉬어야 하므로 건강에 해를 입게 된 다. 이것은 사회적으로 문제가 된다. 이들을 치 료할 막대한 의료비용이 소요될 수 있으며, 이 러한 비용은 교환의 당사자가 아닌 사람들이 부담하게 되기 때문이다. 이러한 부정적 외부성 은 과잉생산되거나 과잉소비되는 경향이 있다. 그러므로 흡연자로 하여금 흡연행위를 어떠한 방법으로 포기하도록 할 것인가의 문제가 있다. 달리 말하면 교환의 당사자가 아닌 사람들에게 어떠한 방법으로 영향을 미치지 않도록 할 것 인가?

여기에서 사람들은 긍정적 외부성을 만들어 보았자 어떤 대가를 받는 것도 아니기 때문에 구태여 이를 만들려 하지 않는 반면에, 부정적 
외부성의 경우에는 이를 만들어내도 아무 대가 를 치르지 않기 때문에 무분별하게 많이 만들 어내는 경향이 있다는 사실에 주목할 필요가 있다. 특히 또 하나의 대표적인 부정적 외부성 의 예로 기업들이 방출하는 오염물질을 들 수 있다. 이러한 오염물질의 방출은 규제가 없는 한, 날로 증가하게 될 것이다. 그러므로 자유로 운 시장기구에 맡길 경우, 긍정적 외부성은 최 적수준보다 더 적게 만들어지는 반면에 부정적 외부성은 최적수준보다 더 많이 만들어지는 결 과가 나타난다. 오염물질의 방출을 완전히 자유 롭게 허용했을 때 우리의 환경이 어떤 모습을 보일 것인가는 상상하기 어렵지 않으며, 여기에 서 외부성의 개넘을 제대로 이해하지 않고서는 올바른 사회마케팅의 전개가 불가능함을 시사 하고 있다.

Bloom and Novelli(1981) 가 주장하였던 바와 같이 형제애(또는 박애정신)보다는 비누를 팔 기가 더 수월할 수가 있다. 그 하나의 이유는 외부성의 존재로 설명할 수 있을 것이다. 이와 관련되는 또 하나의 이유로 형제애를 판매하기 위하여 이용되고 있는 착상 내지 아이디어가 부족한 것을 들 수 있을 것이다. 사회마케팅은 상업마케팅과는 다소 상이한 상황에 처해 있기 때문에 부적절하거나 불충분한 수단이 이용되 고 있다. 본 연구에서는 사회자본이론이 사회마 케팅 종사자들에게 형제애의 판매를 증대시킬 유용한 단서를 제시할 수 있을 뿐만 아니라 이 이론을 조작적으로 정의하는데에도 기여할 수 있음을 보이고자 한다. 사회자본이론은 복잡한 교환개념과 시장실패는 물론 사회적 문제와 행 동문제를 고려하고 있으며, 따라서 이러한 요소 들을 종합적으로 다룰 상황적 적절성을 지니고
있다고 할 수 있다. 이하에서는 사회자본이론에 관하여 논의하고 그것이 사회마케팅과 어떠한 관련이 있는가를 살펴보기로 한다.

\section{IV. 사회자본이론과 사회마케팅에의 응용}

\section{1 사회자본이론의 개념과 성격}

사회자본이론(social capital theory)은 신뢰, 사회적 자원, 사회적 교환, 비공식적 조직, 문 화, 기업간 네트워크, 관계적 계약 및 사회적 지지 등과 같은 개념들이 합쳐진 하나의 포괄 적 이론이라고 할 수 있다(Adler and Kwon 2002; Hirsh and Levin 1999). 이 이론은 Bourdieu (1985)가 창안하여 비교적 근래에 이르러 발전 하였으며 그 근원은 사회학 분야에서 비롯되었 다. 최근에는 이에 대한 관심이 급격히 고조되 어 경제학, 정치학, 및 조직이론 등의 여러 사 회과학 분야에서도 채택되고 있다.

사회자본의 성격과 구성요소에 대해서는 다수 의 견해가 있으나 그 정의는 '사회적 관계들로 구성된 조직(fabric)에 의하여 야기되고 행위를 조장하기 위하여 발휘될 수 있는 호의(goodwill)' 라고 할 수 있다는데 대하여 일반적으로 공감 하고 있다(Adler and Kwon 2002, p.17). 이러 한 정의에는 특히 여러 가지로 중요한 의미가 내포되어 있다. 첫째, 이 정의에서는 '사회적' 관계들과 교류에 관한 착상을 포함시키고 있다. 둘째, '호의'라는 용어는 사회자본이 신뢰를 토 대로 형성되며 구체적인 호혜성은 물론 일반화 
된 호혜성에 근거한 규범에 의존하고 있음을 시사하고 있다는 점이다(Putnam 1995, 2000). 구체적인 호혜성이란 어느 한 사람이 타인에게 호의를 베풀면 그 반대급부로 상대로부터 그러 한 호의를 되돌려 받을 것이라는 믿음을 말한 다. 다른 한편, 일반화된 호혜성은 호의를 베풀 면 어떠한 형태로든 되돌려 받게 된다는 원리 를 토대로 하고 있다. 다시 말하면 어느 한 사 람이 타인에게 호의를 베풀면 어느 시점에서든 지 상대방이 당사자가 아니더라도 반대급부로 그러한 호의를 그에게 되돌려 보낼 것이라는 믿음을 말한다. 이러한 사회자본과 사회마케팅 은 호혜성에 근거한 규범과 Bagozzi(1975)가 규정한 교환의 유형이라는 면에서 상호 밀접한 관련이 있다. 좀더 구체적으로 말하면, 구체적 인 호혜성과 보편적 교환은 성격상 단선적이라 는 점에서 유사하고, 일반화된 호혜성과 복합적 교환은 성격상 상호적이라는 점에서 유사하다 고 할 수 있다. 이러한 논의를 통하여 나오게 되는 핵심적 명제는 신뢰를 고양하고 상호간에 관계를 부여하는 것이 사회마케팅 종사자들의 기본적 목적이고 적극적으로 사회적 변화를 달 성하기 위한 선택사항의 하나라는 것이다. 따라 서 사회마케팅 분야에서 앞으로 더 연구가 진 행되어야 할 과제는 사회마케팅 내에서 신뢰와 호혜성에 근거한 규범을 개발하는 것이다. 그 이유는 신뢰가 시장실패의 효과를 조절할 가능 성이 있기 때문이다.

셋째. '조직(fabric)'이라는 용어는 하나의 네 트워크 시스템을 의미하며, 그러한 네트워크는 느슨한 관계로 연결되거나 공고한 관계로 연결 되는 경우를 모두 포함하고 있다. 네트워크가 존재한다는 것은 곹 상호간에 의무가 있음을
뜻하며, 이러한 상호간 의무는 호혜성에 근거한 규범을 조장한다(Putnam 2000). 사람들은 이러 한 네트워크를 통하여 행위를 집결시킬 수 있 으며, 이는 네트워크를 통하여 정보를 입수하고 영향력을 행사하며 유대를 강화하는 등의 혜택 을 볼 수 있음을 시사하고 있다. 따라서 사회 자본은 사적으로 전용할 수 있다(Adler and Kwon 2002: Putnam 2000). 이것은 사회자본 이 하나의 생산자원임을 의미한다. 이에 따라 사람들은 네트워크가 생산적이 되도록 그것을 구축하고 유지하고자 하며 더불어 신뢰를 구축 하려는 노력을 기울인다(Adler and Kwon 2002: Portes 1998).

사회자본에 관하여는 두 가지 견해가 있다. 그 하나는 내적 견해이고 다른 하나는 외적 견 해이다(Adler and Kwon 2002; Putnam 2000). 내적 견해는 사회정체성 이론과 밀접한 관련이 있는 반면에, 외적 견해는 사회 네트워크 이론 의 관점을 지니고 있다. 내적 견해에 의하면, 사회자본은 행위자들을 결속시키는 사회적' 접 착제'의 역할을 수행한다(Putnam 2000). 이러 한 사회구조는 친척이나 친구와 같이 지속적인 관계를 유지하는 강력한 결속력을 지니고 있는 특징이 있다(Granovetter 1973). 보다 응집된 네 트워크 구조는 규범에 의하여 지배되고 감시하기 가 수월하며, 따라서 신뢰를 촉진한다(Coleman 1988). 또한 그러한 구조 하에서 발생된 응집력 은 집단적 목적의 달성을 촉진시킨다(Adler and Kwon 2002). 그러나 집단의 규범이 지나치게 고착되어 있을 때에는 사회자본이 결속력이 강 한 형태를 띠게 되면 사회자본이 생성되는데 부정적인 결과를 초래할 수 있다. 이것은 사회 마케팅의 관점에서 흥미있는 문제이다. 다른 한 
편 외적 견해에 의하면, 사회자본은 네트워크 내에서 한 개인이 다른 사람들과 맺고 있는 미 약한 관계(이는 면식이 있는 지인(知人) 정도 의 관계와 유사하다)를 연결하는 기능을 수행 한다(Granovetter 1973). 이와 같은 취약한 네 트워크는 구조적으로 결함이 있지만 정보의 흐 름과 확산을 촉진시키는 장점이 있다. 그러나 그러한 구조 내에서는 경쟁적인 적수가 존재하 며 사람들은 자신의 이기심에 의하여 동기가 유발된다. 이러한 맥락에서 보면 사회자본은 하 나의 사유재이다.

사회자본이 효과적으로 생성되어 산출되려면 사회자본의 연결기능과 결속기능이 균형을 이 루고 있는 것이 이상적이다. 사회자본의 연결기 능은 정보제공의 이점을 갖고 있고(Granovetter 1973; Hansen 1999), 이러한 이점의 구체적인 예로 마케팅 정보의 전파를 촉진시키는 경우를 들 수 있다. 이와는 대조적으로 사회자본의 결 속기능은 사회적 규범을 자연적으로 발생시키 는 이점이 있고, 이것은 사회마케팅 종사자들이 행동을 변경시키려는 노력에 도움이 된다. 그러 나 이러한 결속기능은 경우에 따라 사회자본의 형성을 지배할 수 있다. 만일 사회구조 내에서 개인들간의 유대가 지나치게 강력하면 여타의 사람들이 배제될 수 있다(Portes 1998). 이렇게 되면 사회 네트워크간에 정보의 전파가 저해되 고, 새로운 아이디어가 사회구조에 도입되기가 어렵게 된다. 이것은 사회마케팅 종사자들이 사 회적 문제에 관한 정보를 다수의 대중들에게 알리고자 할 경우에 문제가 될 수 있다. 또 하 나의 문제는 Portes(1998)가 언급한 바 있는 규 범의 하향 평준화 현상으로서, 이것은 사람들이 현재의 입지를 고수함으로써 그들의 사회구조
에 속해 있지 않은 사람들을 차별하는 것을 말한 다. 이것 역시 사회 네트워크간에 정보의 흐름을 저해하며 부가적으로 지대추구(rent-seeking)를 조장한다. 사회적 유대관계가 지나치게 고착될 때 규범에의 순응이 보장됨으로써 개인의 자유 가 제약받게 된다는 것도 문제가 된다. 이것은 규범이 어떤 관습에 대한 순응을 확실하게 보증 하고 현상유지의 의지가 변화에 저항할 경우에 사회마케팅 종사자들이 행동변화를 촉진시킬 수 있는 능력을 저해할 수 있음을 의미한다.

사회마케팅 종사자들은 교환관계에 대해 일반 화된 신뢰를 심화시킬 때 이러한 문제들에 대 해 각기 대처해 나갈 수 있을 것이다. 앞에서 언급하였던 바와 같이 공공재는 비경합성과 배 제불가능성이라는 두 가지 특성으로 인하여 사 람들은 소비하는데 무임승차의 유혹을 갖기 쉽 다. 사회자본이 결속기능을 갖게 되면 소비 내 지 이용이 비경합성을 띄게 되므로 공공재의 성격을 갖는다. 바꾸어 말하면, 어느 한 사람이 강력한 네트워크 기반을 이용한다고 하여 다른 사람들이 이를 이용하는 것을 막을 수는 없다. 그러나 네트워크 자쳬는 배제가능하며, 이와 같 이 배제가능한 네트워크는 무임승차하고자 하 는 유혹을 희석시키고 재산권의 확립을 촉진한 다. 사람들은 규범에 순응하지 않을 때 사회구 조에서 배제되리라는 위협을 받게 될 때 그러 한 규범에 집착하게 된다. 따라서 사회마케팅 종사자들도 무임승차의 현상이 나타나는 환경 에 접하게 되므로 규범의 역할과 배제가능성 문제를 이해하는 것이 중요하다.

사회자본의 이점은 사회구조 내에서의 사회적 관계에서 나오며 그러한 구조 내에서 개인의 위치에 달려 있다(Adler and Kwon 2002). 사 
회구조는 사회적 관계를 구성할 뿐만 아니라 시장관계와 계층관계도 구성하며. 시장관계와 계층관계는 모두 사회자본의 창출에 간접적으 로 기여하고 있다(Adler and Kwon 2002). 여 기에서 말하는 시장관계란 Bagozzi(1975)가 언 급한 한정된 교환의 개넘에 해당된다고 할 수 있으며, 계층관계는 권위에 대한 순응을 확실하 게 보장할 수 있는 통제 메카니즘을 말한다. 또 한 균형적 교환을 촉진시키기 위하여 통제권이 행사되며, 그러한 통제는 규범에 의한 사회적 관계와 네트워크에서 배제하겠다는 위헙을 통 하여 그 목적을 달성한다. 사람들이 규범에 확 실하게 순응하게 되는 것은 개인적으로는 네트 워크의 이득을 입수할 수 있고 집단적으로는 네트워크의 이득을 높일 수 있기 때문일 것이 다. 그러나 네트워크 이득만이 사람들이 교환에 적절하게 참여하는 유일한 이유는 아니며 다만 사회자본이론이 이에 관한 단서를 제공할 수 있을 것으로 생각된다. 여타 여러 가지 이유에 관하여는 추가로 연구하여야 할 과제이다.

\section{2 사회마케팅에의 응용}

지금까지 논의한 사회자본이론의 성격과 개념 은 사회마케팅에 어떻게 응용할 수 있는가를 좀더 구체적으로 살펴보기로 한다. 먼저 상업마 케팅은 물론 사회마케팅에서도 시장실패의 문 제에 관하여 지금까지 관심을 기울이지 않았다 는 점에 유의할 필요가 있다.

여기에서는 시장실패의 대표적인 요인인 외부 성에 초점을 두어 사회자본이론의 응용가능성을 검토하기로 한다. 우선 긍정적 외부성과 관련되 는 문제(즉, 어느 한 개인이 교환에 참여하고자
하는 인센티브를 갖고 있지 않는 사람에게 어떻 게 판매할 것인가의 문제)는 앞에서 제기한 바 있다. 사회자본이론은 이러한 문제에 접근하는 한 가지 방법이 네트워크의 이득을 이용하는 것 임을 암시하고 있다. 네트워크의 이득을 이용하 게 되면 이기심에 의하여 동기가 유발되는 사람 에게도 교환에 참여할 인센티브가 발생한다.

사회마케팅 종사자들에 대한 사회자본이론의 유용성은 앞에서 언급한 면역성 부여의 경우를 대표적인 예로 들 수 있다. 면역을 위한 예방접 종이 통상적인 관행으로 되어 있을 때. 일부 사 람들이 이를 거부하면 그들이 속해있는 사회 네트워크에서 배제될 수 있다. 이러한 네트워크 는 여러 가지 이득을 부여한다. 예컨대 필요한 자금을 융통할 출처를 제공한다거나, 비밀을 털 어놓는다든가, 또는 유익한 정보를 입수할 수 있게 되는 경우 등이 이에 속한다. 따라서 그들 은 규범에 순응하거나, 아니면 기존의 행동을 계속 유지함으로써 네트워크와 네트워크가 지 니고 있는 이득을 상실하게 된다. 이것은 두 가 지 대안이 있음을 가리키고 있다. 경제학에서 나온 기회비용의 개념은 사회자본이론과 함께 사회마케팅 종사자들이 생각하는 '가격'문제에 유용한 단서가 될 수 있다. 기회비용이란 널리 알려져 있는 바와 같이 한 개인이 가장 선호하 는 것을 입수하기 위하여 포기하여야 되는 차 선의 대안을 말한다. 사회마케팅 환경에서 이것 은 한 개인이 제품을 구입하기 위하여 소요되 는 비용을 지칭한다. 그러므로 사회마케팅 종사 자는 소비자의 눈에 비추어 문제의 교환의 비 용이 덜 소요되도록 과거에 비하여 행동변화가 보다 긍정적인 것처럼 보이도록 함과 동시에 네트워크의 이득 상실이 크다는 인상을 심어줄 
필요가 있다. 이것은 앞으로 더 탐구할 필요가 있는 분야이다.

본 연구에서는 Andreasen(1994)이 언급한 행 동변화 또는 행동에 영향을 미치는 것이 사회 마케팅의 주요 '제품'이라고 간주하고자 한다. 이와 더불어 사회마케팅은 개인의 행동변화를 가져오도록 충분한 변화의 효과와 사회의 이득 을 위해 호의를 발생시키기 위한 마케팅 활동 을 전개하는 것으로 보아야 한다는 입장을 취 하고자 한다. 네트워크의 이득은 네트워크내의 여타 행위자들을 통하여 얻게 된다. 각 개인과 네트워크는 서로 연결되어 있으며 Burt(1998) 는 이를 '경계선상의 연결고리'라고 명명한 바 있다. 개인들은 관계적 유대를 통하여 타인들 과 연결된다. 각 개인이 타인들과 연결될 수 있을 때 느슨하게 결속되어있는 사회구조는 보 다 효과적으로 기능할 것이고 총체적으로 보다 많은 이득을 낳을 것이다(Burt 1998; Koka and Prescott 2002). 변화가 발생하게 되면 그러한 사회구조는 상이한 네트워크를 통하여 성립될 것이다. 다시 말하면 사회적 네트워크보다는 개 인적 네트워크가 동원됨으로써 성립된다. 여기 에서 사회적 네트워크는 개인적 네트워크를 통 한 집단적 내지 사회적 결과를 낳는다. 따라서 경계선상의 연결고리는 극히 중요한 역할을 수 행한다고 할 수 있다. 경계선상의 연결고리가 다수의 네트워크를 동원하고 영향을 미치는 능 력을 갖고 있기 때문에 사회마케팅 종사자들은 경계선상의 연결고리에 촉진활동을 집중할 필 요가 있을 것으로 생각된다. 이러한 경계선상의 연결고리는 정보를 전파하는데 중요한 역할을 수행하기 때문에(Burt 1998) 연결고리로 이어 진 네트워크를 구성하고 있는 여타 행위자들에
게 아이디어를 '촉진'시킬 수 있다(Kotler and Zaltman 1971). 경계선상의 연결고리는 여타 네트워크의 이득에 대한 접근을 고무하거나 거 부하는 '장(場)'이 될 수도 있다. 사회마케팅 캠 페인의 촉진에 대한 또하나의 단서는 사회자본 의 결속기능에서 도출할 수 있다. 이러한 결속 기능은 한 개인의 '외집단(outgroup)' (규범을 긍정적으로 따르려는 여타 개인들)이 그의 '내 집단(ingroup)' (부정적 행동을 시도하는 개인 들)보다 더 돋보이거나 매력적이 되도록 조장 하는 역할을 수행할 것이다(Hogg and Abrams 1988). 이와 같이 내집단에 비한 외집단의 긍정 적 이미지를 창출하는데 역점을 두는 방편은 전통적인 촉진수단으로 보완될 수 있을 것이다.

\section{2 .1 응용의 예 (1)-흡연의 경우}

이러한 논거를 토대로 흡연의 경우를 예로 하 여 사회마케팅에 대한 사회자본이론의 응용가 능성을 보일 수 있다. 앞에서 언급하였던 바와 같이 흡연은 교환의 당사자가 아닌 사람들에게 부정적 영향을 미친다. 즉, 흡연은 부정적 외부 성의 결과를 초래한다. 여기에서 사회마케팅 종 사자가 판매하려는 '제품'은 흡연하지 않는 사 람들이 모인 곳에서 금연하도록 하거나 흡연습 관을 포기하도록 하는 것이다. 마케팅 종사자의 핵심적 역할은 흡연하지 않으면 생활이 즐겁고. 친구를 더 많이 사궐수 있으며, 재산증식도 가 능하다는 등의 아이디어를 촉진하는 것이다. 이 것은 흡연자의 입장에서 보면 많은 사람들이 긍정적 관점에서 이해하여 주기를 바라기 때문 에 불편한 느낌을 갖게 된다. 이러한 긴장의 발 생으로 행동이 수정되는 결과를 낳을 수 있다. 
예컨대 광고에서 어느 유명인사가 흡연자의 곁 을 떠나는 장면을 보이면서 '귀하는 지금 누구 와 같이 있는지 알고 있습니까?'라는 문구가 들 어있을 경우에 그러한 결과가 초래될 수 있을 것이다. 그러나 이것은 그 효과가 일시적이기 때문에 개인의 행동을 변경시키는 데에는 한계 가 있을 것으로 생각된다. Bennett(1998)에 의 하면 위협전술은 부적절한 행동을 증폭시키는 것과 같은 부정적 결과를 낳을 수 있기 때문에 효과를 거둘 수 없다. 따라서 금연을 촉진시킬 것을 목적으로 하는 캠페인에 위협전술을 이용 한다는 것은 문제가 있음을 시사하고 있다. 그 러므로 여타 유형의 마케팅 정보를 전파하는 데에는 경계선상의 연결고리를 고려할 필요가 있다. 이러한 경계선상의 연결고리는 인적판매 의 역할에 비유할 수 있다. 이에 속하는 행위자 들에게는 행동규범을 시행하고 변경할 힘을 부 여할 필요가 있다.

이것은 사회마케팅 종사자가 그러한 경계선상 의 연결고리가 지니고 있는 힘과 영향력을 이 해하고 이를 이용할 수 있어야 함을 시사하고 있다. 만일 네트워크내의 행위자들이 네트워크 의 이득을 철회한다면(또는 비용을 부과한다 면) 흡연자는 상실된 이득을 되찾기 위하여 이 기심에 의하여 동기가 유발될 수 있다. 다시 말 하면, 흡연자는 흡연을 계속하여 네트워크의 이 득을 상실하든가, 아니면 흡연을 중단할 것이 다. 그가 포기한 선택방안은 그가 거부하게 된 하나의 '대가'(또는 가격)이다. 규범을 지키지 않았을 때 그러한 규범이 개인을 제거할 힘을 갖고 있으면 그는 교환관계에 기꺼이 참여함으 로써 교환에 참여하지 않는 사람들에게 영향을 미치지 않을 수 있다.

\section{2 .2 응용의 예 (2)-저출산율과 신용불량자 문제}

사회마케팅에 대한 사회자본이론의 응용가능 성은 이상의 흡연뿐만 아니라 다수의 사회적 문제에서도 찾을 수 있다. 특히 우리나라의 경 우, 근래에 이르러 대두된 사회적 문제의 대표 적인 예로 저(低)출산율에 따른 노년층 인구의 급격한 증가와 신용불량자의 양산을 들 수 있 다. 양자가 모두 우리 경제성장에 발목을 잡고 있는 병목현상이라 할 수 있으며 부정적 외부 성의 결과를 초래한다. 저출산율은 산업생산인 력의 감소와 연금에 의존하는 노년층의 증가로 이어지고 이들을 위한 정부의 복지예산을 감당 하려면 젊은 층의 담세증가가 불가피하다. 이에 따라 젊은층의 소비감소와 근로의욕 감퇴와 함 께 과도한 노인복지 예산으로 정부재정이 만성 적자가 누적된다. 문제는 저출산율을 극복하기 위하여 육아수당, 육아부모 휴직제 등의 출산촉 진책만으로는 효과가 없다는데 있다. 보다 근본 적인 해결책은 교육의 수준을 파격적으로 늘여 인구의 지적(知的) - 기술적 질(質)을 고도화하 는 장기적 계획을 수립, 실행하는 것 뿐이다. 여기에 사회자본이론의 유용성이 있다. 4 백만명 에 이르는 신용불량자의 경우에도 저출산율 문 제와 동일한 맥락에서 대처할 수 있다. 신용불 량자에 대한 부채상환의 연기나 유예와 같은 조치는 오히려 도덕적 해이를 조장하는 역기능 을 초래하는 단기적인 미봉책에 불과하다. 흡연 의 경우와 마찬가지로 저출산율과 신용불량자 와 같은 사회적 문제는 대상자들에 대한 장 단기적 '촉진'계획과 아울러 다수의 네트워크를 동원하고 영향을 미칠 힘을 갖고 있는 경계선 
상의 연결고리에 촉진활동을 집중할 필요가 있 음을 시사하고 있다.

Wiener(1993)는 이와 유사한 맥락에서 사회 마케팅에 관한 실증연구를 통하여 지역주민들 이 지역사회의 발전에 기여할 사업에 대한 의 사결정을 내리는데 자신들의 자유를 포기하도 록 하는 힘이 존재하고 있음을 발견하였다. 그 러므로 사회자본이론은 사회마케팅 종사자들에 게 실질적인 안목을 제시할 수 있을 것이다.

본 연구는 사회자본이론이 사회마케 팅에 관한 전통적 접근방법이나 학제간 접근방법을 대체할 수 있다고 제안하는 것은 아니다. 그보다는 사 회자본이론이 사회마케팅을 보다 효과적으로 실 행하는데 하나의 유용한 준거틀이 될 수 있다고 주장하고자 한다. 실제로 적극적인 사회적 변화 를 추구하려면 전통적 수단과 학제간 접근방법 에서의 개인적 및 사회적 접근방법. 그리고 사 회자본이론이 포괄적으로 원용될 필요가 있다.

\section{3 응용상의 문제점}

지금까지 본 연구에서는 시장실패에 초점을 두어 사회자본이론이 사회마케팅에 어떻게 기 여할 수 있는가를 살펴보았다. 그 중에서도 와 부성에 국한하여 논의하였다. 그러나 여기에는 몇 가지 문제가 있다.

첫째, 본 연구에서는 시장실패를 가져오는 주 요 요인으로 외부성과 공공재의 존재를 예시하 고, 그 중에서도 외부성으로 인하여 초래된 시 장실패의 환경내에서 사회마케팅이 존재한다고 생각되어 외부성의 예를 들어 사회자본을 사회 마케팅에 응용할 방법을 탐구하였으나. 시장실 패를 가져오는 요인으로는 그밖에도 불완전경
쟁으로 인한 독점화 현상과 불확실성 내지 불 완전한 정보의 존재도 있다는 점에 유의할 필 요가 있다(이준구 2004). 이러한 요인들도 사희 마케팅에서 다루어야 할 문제이지만 본 연구의 주제와 다소 거리가 있어 이와 관련한 사회마 케팅에의 응용가능성은 다루지 않았다.

둘째, 본 연구에서는 사회자본의 개념을 사희 마케팅에 응용하는데 그 유용성만을 언급하였으 나 위험도 뒤따르는 문제가 있다. 예컨대 사회 자본이 형성되려면 관계를 구축하고 유지하는데 상당한 투자가 필요하며, 이러한 투자는 경우에 따라 비효율적일 수 있다. 좀더 구체적으로 말 하면, 한 조직내에서 여타의 팀들과 강력한 유 대관계를 갖고 있는 팀이 미약한 유대관계를 갖 고 있는 팀보다 과업을 완수하는데 더 많은 시 간을 소비할 수 있고, 전자가 후자에 비하여 정 보입수의 이득이 있어도 팀을 유지하는데 과도 한 비용이 소요될 수 있다. 이러한 의미에서 본 연구에서 사회자본을 '주어진' 것으로 가정한 것 은 사회자본의 성격을 오도할 우려가 있다.

셋째, 사회자본은 광범위한 정보출처에 접근 함으로써 정보를 용이하게 입수할 수 있다는 것이 가장 커다란 장점이지만, 그러한 정보상의 이득은 사회자본의 또 하나의 장점인 영향력, 통제 및 힘의 행사라는 이득과 상쇄될 수 있다. 예컨대 네트워크내의 행위자가 여타 사람들과 유대관계를 맺고 접촉하는 다수의 행위자들과 교류할 경우에 소수의 행위자들과 접촉할 때보 다 덜 의존하는 경향이 있을 수 있다.

그러므로 사회마케팅 종사자의 입장에서는 사 회자본을 응용하고자 할 때에는 그것이 지니고 있는 장점과 위험이 적절하게 균형을 이루도록 충분히 고려하여야 한다. 


\section{V. 결 론}

\section{1 연구의 요약}

사회마케팅 분야는 마케팅 개념의 확장에서 비롯되었으며, 이에 따라 사회마케팅 종사자들 은 사회적 문제를 다루는데 전통적인 마케팅 수단에 주로 의존하는 경향이 있다. 이와 더불 어 사회마케팅에 관한 지금까지의 연구문헌들 은 사회마케팅 종사자들이 당면하고 있는 시장 실패와 복잡한 교환을 특징으로 하는 상황을 간과하고 있음을 보이고 있다. 이러한 상황은 상업마케팅의 경우와 상이하며. 따라서 전통적 인 마케팅 수단만으로 사회적 문제를 다룰 수 없다. 본 연구에서는 사회자본이론이 시장실패 와 복잡한 교환은 물론 행동변화와 사화현상도 모두 고려하고 있기 때문에 사회마케팅 종사자 들에게 유용하다는 점을 보여주었다. 따라서 사 회마케팅에 사회자본이론을 원용하면 유익한 사회적 변화를 달성하는데 하나의 지침이 될 것이다.

\section{2 연구의 한계와 미래의 연구방향}

본 연구에서는 시장실패와 복잡한 교환을 특 징으로 하는 상황에서 사회자본이론을 사회마 케팅에 원용하면 사회마케팅의 응용을 확장할 수 있음을 보여주었으나, 그것만으로 사회마케팅 이 더 활성화 되리라는 보장은 없다. Andreasen (2002)이 언급한 바와 같이, 21세기에 들어 사 회마케팅은 성장기에 접어들었으나, 성장기가 지속되려면 몇 가지 장애요인이 극복되어야 한
다. 그러한 장애요인 중의 하나는 본 연구에서 다룬 외부성과 공공재 문제는 주로 정부를 비 롯한 비영리기관의 경영자들이 사회마케팅 관 점에서 접근할 필요가 있으나 이에 대한 이해 가 부족하다는 점이다. 따라서 사회마케팅의 의 의와 중요성을 시장실패의 측면에서 이들에게 주입시킬 필요가 있다.

두 번째 장애요인은 사회적 변화를 달성하려 는 사회마케팅의 개넘이 명확하지 않고 그 정 의도 다양하다는 것이다. 따라서 학문적 입장에 서 확고한 위치를 갖고 있지 못하다. 특히 마케 팅 분야에서 정규과목으로 대학에서 개설하는 경우가 매우 드물다. 물론 지금까지 비영리기관 에서 실무적으로 상업마케팅의 수단을 많이 이 용하여 왔고 연구도 축적되었지만, 그것만으로 는 사회마케팅 고유의 개념과 이론을 발전시킬 수 없을 것이다. 사회마케팅이 좀더 발전하려면 지금까지의 연구결과들을 체계적으로 평가함과 동시에 학제간 접근방법을 강화할 필요가 있다.

세 번째 장애요인은 윤리적 문제와 관련이 있 다. 마케팅 관리학파가 중심이 되는 오늘날의 상업마케팅이 왜곡된 소비의 조장. 환경오염, 인권유린 및 계층간의 소득격차 확대 등 사회 적으로 바람직하지 못한 결과를 초래하고 있다 는 다수의 비판이 제기되고 있다(여운승 2003). 사회마케팅도 예외일 수 없다. 그러나 사회마케 팅은 사회적 문제를 다룬다는데 상업마케팅과 차별되며 표적고객이 '일반 대중'이라는 특징이 있다. 여기에서 대중의 개인적 복지와 사회적 복지가 상치될 수가 있다. 따라서 사회적 복지 를 흭일적으로 '촉진’하게 되면 개인적 복지가 희생될 우려가 있다. 이를 어떠한 방법으로 해 결할 것인가의 문제가 사회마케팅의 주요 과제 
이다. 본 연구에서는 이러한 장애요인들을 극복 할 대안을 제시하지 못하였다. 그러한 대안을 제시하려면 광범위한 연구가 필요하며, 따라서 차후의 연구과제로 남겨두기로 한다.

마지막으로 본 연구에서는 사회마케팅이 시장 실패 문제에 접근하려면 사회자본이론이 적절 하다는 것을 보여주었으나, 사회자본이론을 통 하여 사회마케팅의 응용을 한 단계 높이려면 관계마케팅(relationship marketing)의 개념을 도입할 필요가 있다(Hastings 2003)는 점에 주 목할 필요가 있다. 단기적인 거래보다는 장기적 인 관계를 중시하는 이 개넘은 상업마케팅보다 사회마케팅에 더 적절하다고 생각되기 때문이 다. 단기적 거래에 초점을 두는 주류 마케팅관 리학퐈의 한계를 극복하기 위하여 1990년대 초 부터 상업마케팅에서 도입되기 시작한 관계마 케팅은 개별적 거래보다는 고객 및 모든 이해 관계 당사자들과 상호 유익한 장기적 관계를 구축하는 것을 중시하고 있다. 유감스럽게도 사 회마케팅에서는 그 중요성을 아직까지도 간과 하고 있는 경향이 있다. '일반 대중'을 표적집단 으로 그들의 행동변화를 달성하려는 사회마케 팅 종사자의 입장에서는 보다 장기적으로 표적 집단 및 이해관계 당사자들과 관계를 구축하는 일이 중요한 과업이 아닐 수 없다. 따라서 사회 마케팅이 이러한 관계지향적 패러다임을 수용 하고 발전시킬 때 적극적이고 혁신적인 사회적 변화를 도모할 수 있을 것이다.

〈논문 접수일: 2005. 01. 25〉 〈게재 확정일: 2005, 04. 11〉

\section{참고문헌}

김수영(2001), "사회복지기관의 자원개발 마케 팅 전랴에 관한 연구," 국립보건원보, 제38 권 (2001. 12), 355-65.

김지민, 이상빈, 리대룡(2002), “사회적 마케팅 의 성적 소구 효과," 광고문화론집, 제8권 제1호, 25-39.

부경희(2001), “신뢰의 사회마케팅: 경쟁 가치

관 분석을 통한 컨셉 개발과정을 중심으 로," 홍보학연구, 제5권 제2호, 5-14.

신준섭, 최은미(2004), “사회복지조직의 마케팅

활성화 방안에 관한 연구: 아동복지시설의 후원사업을 중심으로." 한국정책과학회보, 제8권 제2호. 137-59.

여운승(2003), "주류 마케팅 사상과 관행에 대한 비판적 고찰," 마케팅연구, 제18권 제2호. $21-51$.

이준구(2004), 미시경제학. 법문사.

Adler, Paul S and Kwon, Seok-Woo(2002), "Social

Capital: Prospects for a New Concept," Academy of Management Review 21(1). $17-40$.

Andreasen, Alan R.(1984), “A Power Potential Approach to Middlemen Strategies in Social Marketing," European Journal of Marketing, 18(4), 56-71.

(1994), "Social Marketing Definition and Domain." Jounal of Public Public Policy and Marketing, 13(1), 108-14. (2002). "Marketing Social Marketing in the Social Change Market Place," 
Journal of Public Policy \& Marketing, 21(1), 3-13.

Bagozzi, Richard P.(1975), "Marketing as Exchange," Journal of Marketing, 39(4). 32-39.

Barach, Jeffrey A.(1984), "Applying Marketing Principles to Social Causes," Business Horizons July/August, 65-9.

Bartels, Robert(1974), "The Identity Crisis in Marketing," Joumal of Marketing, 38(October), 73-6.

Bennett Roger(1998), "Shame, Guilt and Responses to Nonprofit and Public Sector Ads," International Journal of Advertising, 17(4), 483-99.

Black, T. R. .L and Farley, John U(1979), "The Application of Market Research in Contraceptive Social Marketing in Rural Area of Kenya," Joumal of Market Research Society, 21(1), 30-43.

Bloom, Paul N and Novelli, William D(1981).

"Problems and Challenges in Social Marketing," Journal of Marketing, 45(Spring). 79-88.

Bourdieu, Pierre(1985), "The Forms of Capital," in J.G. Richardson(ed), Handbook of Theory and Research for the Sociology of Education 24(1), 21-8.

Brenkert, George G(2002), "Ethical Challenges in Social Marketing," Jounal of Public Public Policy and Marketing, 21(1), 14-25. Brown, Kelli McCormack, Bryant, Carol A, Forthofer, Melinda S. Perrin, Karen M.
Quinn, Gwendolyn P, Wolper, Michelle and Lindenberger, James H(2000), "Florida Cares for Women Social Marketing Campaign: A Case Study," American Journal of Health Behavior, 24(1), 44-52.

Burt, Ronald S(1998), "The Gender of Social Capital," Rationality and Society, 10(1), 5-46.

Cirksena, M K and Flora, J. A(1995), "Audience Segmentation in Worksite Health PromotionA Procedure Using Social Marketing Concepts." Health Education Research, 10(2), 211-24.

Coleman, James S(1988), "Social Capital in the Creation of Human Capital," American Journal of Sociology, 94(Supplement), S95S120.

David, Sean P and Greer, David S(2001), "Social Marketing: Application to Medical Education," Annals of Internal Medicine, 134(2), 125-27.

Enis, Ben M(1973), "Deepening the Concept of Marketing," Journal of Marketing, 37(4). 57-62.

Fox, Karen F and Kotler, Philip(1980), "The Marketing of Social Causes: The First Ten Years," Journal of Marketing, 44(4), 24-33.

Foxall, Gordon(1989), "Marketing's Domain," European Journal of Marketing, 23(8), 7-22. Golden, Linda L and Johnson, Keren Ami (1991), "Information Acquisition and Behavioral Change: A Social Marketing Ap- 
plication," Health Marketing Quarterly, 8(3/4), 23-60.

Granovetter, Mark S(1973), "The Strength of Weak Ties," American Journal of Sociology, 78, 1360-80.

Hansen, Morten T(1999), "The Search-Transfer Problem: The Role of Weak Ties in Sharing Knowledge Across Organization Subunits," Administrative Science Quarterly, 44(1), 82-111.

Hastings, Gerard(2003), "Relational Paradigms in Social Marketing," Journal of Macromarketing. 23(1), 6-15.

Hirsch, Paul M and Levin Daniel Z(1999), "Umbrella Advocates Versus Validity Police: A Life Cycle Model," Organization Science, 10(2), 199-212.

Hogg. Michael A and Abrams. Dominic(1988), Social Identification: A Social Psychology of Intergroup Relations and Group Processes, London: Routledge.

Jones, David B(2001), “Marketing Psychological Services: Using Client Problem and Solution Perception to Design Help Offering Promotional Appeals," Psychology and Marketing, 18(3), 261-79.

Koka, Balaji R and Prescott, John E(2002), "Strategic Alliances as Social Capital: A Multidimensional View." Strategic Management Journal, 23(9), 795-816.

Kotler, Philip(1972), "A Generic Concept of Marketing," Journal of Marketing. 36(April), $46-54$.
(1988), Marketing Management: Analysis, Planning, Implementation and Control, New Jersey: Prentice Hall.

Kotler, Philip and Levy, Sidney J(1969), "Broadening the Concept of Marketing," Joumal of Marketing, 33(1), 10-15.

Kotler, Philip and Zaltman, Gerald(1971), "Social Marketing: An Approach to Planned Social Change," Journal of Marketing, 35(3). 3-12.

Laczniak, Gene R and Michie, Donald A(1979), "The Social Disorder of the Broadened Concept of Marketing," Journal of the Academy of Marketing Science, 7(3), 214-31. Laczniak, Gene R, Lush, Robert F and Murphy, Patrick E(1979), "Social Marketing: Its Ethical Dimensions," Journal of Marketing, 43(Spring), 29-36.

Luck, David J(1969), "Broadening the Concept of Marketing-Too Far," Journal of Marketing, 33(July), 53-5.

(1974), "Social Marketing-Confusion Compounded," Journal of Marketing, 38(4), 70-2.

Martin, Garth W., Herie, Marilyn A., Turner, Bonnie J and Cunningham, John A(1988), "A Social Marketing Model for Disseminating Research-Based Treatments to Addictions Treatment Providers," Addiction, 93(11), 1703-15.

Maslow, Abrahaam(1954). Motivation and Personality, New York: Harper and Row. McKenzie-Mohr, Doug(1994), "Social Marke- 
ting for Sustainability-The Case of Residential Energy-Conservation," Futures, 26(2), 224-33.

Moore, Jesse N, Raymond, Mary Anne, Mittelstaedt, John D and Tanner, John F Jr (2002). "Age and Consumer Socialization Agent Influences on Adolescents' Sexual Knowiedge, Attitudes, and Behavior: Inplications for Social Marketimg Initiatives and Public Policy," Journal of Public Policy and Marketing, 21(1), 37-52.

Ornstein, Stanley I and Hanssens, Dominique M(1985), "Alcohol Control Laws and the Consumption of Distilled Spirits and Beer," Journal of Consumer Research, 12(2), 200-13.

Peattie, Ken, Peattie Sue and Clarke, Philip (2001). "Skin Cancer Prevention: Reevaluating the Public Policy Implications," Journal of Public Policy and Marketing, 20(2), 268-79.

Portes, Alejandro(1998), "Social Capital: Its Origines and Applications in Modern Sociology," Annual Review of Sociology, 24. 1-24.

Price, Neil(2001), "The Performance of Social Marketing in Reaching the Poor and Vulnerable in AIDS Control Programmers," Health Policy and Planning, 16(3), 231-39. Putnam, Robert D(1995), "Bowling Alone: America's Declining Social Capital," Joumal of Democracy, 6(1), 65-78. (2000). Bowling Alone: The Collapse and Revival of American Community, New York: Touchstone.

Reichert, Tom, Heckler, Susan E and Jackson, Sally(2001), "The Effects of Sexual Social Marketing Appleals on Cognitive Processing and Persuasion," Journal of Advertising XXX(1), 13-27.

Sheth, Jagdish N. and Parvatiyar, A(2002), "Evolving Relationship Marketing into a Discipline," Journal of Relationship Marketing. 1(1), 3-16.

Sirgy M. Joseph, Morris Michael and Samli, A. Coskun(1985), "The Question of Value in Social Marketing: The Use of Quality-OfLife Theory to Achieve Long-Term Life Satisfaction," The American Journal of Economics and Sociology, 44(2), 215-28. Smith, William(2000), "Social Marketing: An Evolving Definition," American Journal of Health Behavior, 24(1), 11-17.

Steiner, George A(1979), Strategic Planning:

What Every Manager Must Know, New York: Free Press.

Tansey, Richard, Hyman, Michael R and Brown, Gene(1992), "Ethical Judgements About Wartime Ads Depicting Combat," Journal of Advertising, XXI(3), 57-74.

Tucker, W. T(1974), "Future Directions in Marketing Theory," Journal of Marketing. 38(April), 30-5.

Walsh, Diana C. Rudd, Rima E. Moeykens, Thomas W(1993), "Social Marketing for Public Heaith," Health Affairs, 12(2), 
104-19.

Wiebe, G. D. (1951-52), "Merchandising Commodities and Citizenship on Television." Public Opinion Quarterly, 15(Winter), 679-91.
Wiener, Joshua L(1993), "What Makes People Sacrifice Their Freedom from the Good of Their Community?" Joumal of Public Policy \& Marketing, 12(2), 244-51. 


\title{
Exploring the Application Extension of Social Marketing Based on Social Capital Theory
}

\author{
Woon-Seung Yeo*
}

\begin{abstract}
Social marketing emerged as a significant paradigm in the late 1960s when the conceptual boundaries of marketing were broadened by some scholars. Accordingly, social marketers have tended to apply traditional marketing tools, albeit within a vastly different context. After reviewing and classifying the social marketing literature into traditional and interdisciplinary approach, the author found out that both approaches disregarded the special context in which social marketing operated. In this regard, the author maintains that social marketers, operating in an environment that is characterized by intricate exchange and amplified market failure brought about by externalities, may be ill-equipped to foster change utilizing conventional marketing tools. Therefore, this paper proposes that social capital is an appropriate theory to supplement traditional notions of marketing to further enhance the field of social marketing as it takes into account market failure, intricate exchange, and behavioral and social phenomena.
\end{abstract}

Keywords: externalities, intricate exchange, marketing concept, market failure, social capital theory, social marketing.

* Professor, School of Management, Hanyang University 